\title{
JUSTIFICAÇÃO, COERÊNCIA E CIRCULARIDADE
}

Júlio César Burdzinski

SÍNTESE - Este artigo está organizado do seguinte modo: na primeira seção, apresento as raízes histórico-filosóficas dos problemas do conhecimento e da justificação; na segunda, traço a distinção entre verdade e justificação epistêmica; a terceira seção é dedicada ao problema da circularidade, problema tradicionalmente imputado ao coerentismo; na quarta seção, apresento uma noção heterodoxa de justificação, a justificação sistêmica; na quinta, apresento e critico uma outra noção heterodoxa de justificação, a justificação inferencial não-linear; na sexta seção, apresento mais algumas distinções importantes e destaco as formas proposicional e doxástica da justificação; o exame destas formas é desenvolvido subseqüentemente na sétima seção; concluo o artigo com uma reflexão acerca da natureza e dos limites de minha proposta.

PALAVRAS-CHAVE - Conhecimento. Coerentismo. Circularidade. Justificação epistêmica. Justificação proposicional. Justificação doxástica.
ABSTRACT - This paper has the following structure: on the first section, I report on the historical and philosophical roots of the problems of knowledge and justification; on the second, I lay out the distinction between truth and epistemic justification; the third section is devoted to the problem of circularity, a problem often attributed to coherentism; on the fourth section, I introduce an unorthodox notion of justification, systemic justification; on the fifth, I present and criticize another unorthodox notion of justification, non-linear inferential justification; on the sixth, I discuss a few other distinctions and focus on the propositional and doxastic forms of justification; the examination of those forms is subsequently developed on the seventh section; I conclude with a reflection on the nature and limits of my proposal.

KEY WORDS - Knowledge. Coherentism. Circularity. Epistemic justification. Propositional justification. Doxastic justification.

\section{Duas notas de História da Filosofia, como introdução}

\subsection{Platão e o problema do conhecimento}

É um lugar comum em Filosofia a afirmação de que o período moderno é o momento da instauração da Teoria do Conhecimento como um conjunto de problemas filosóficos específicos privilegiado. Falar de uma teoria do conhecimento em Platão é, desde esse ponto de vista, dar mostras de uma carência de rigor

* Departamento de Filosofia. Universidade Federal de Santa Catarina (UFSC).

\begin{tabular}{|l|l|l|l|l|l|}
\hline VERITAS & Porto Alegre & v. 50 & n. 4 & Dezembro 2005 & p. 65-93 \\
\hline
\end{tabular}


histórico-filosófico. Porém, se de fato é somente a partir da polêmica entre o racionalismo e o empirismo, inaugurada no século XVI, que a questão do conhecimento passa a ser apresentada como a questão filosófica por excelência, também é certo que a discussão sobre o conceito de conhecimento não é estranha ao pensamento clássico. O que ocorre é que nos autores desse período o equacionamento da problemática epistemológica se constrói invariavelmente ligado - e, via de regra, subordinado - ao arcabouço metafísico que cada um deles articula. Em Platão, a interrogação sobre o conhecimento surge invariavelmente ligada ao questionamento ontológico e, em seguida, à reflexão ética e política. Por isso mesmo, apresentar a teoria do conhecimento platônica requer que busquemos elementos para essa discussão em meio a um contexto especulativo mais amplo, contexto no qual diversas tramas conceituais estão entretecidas.

Não é o caso de percorrer aqui, mesmo que brevemente, os ligamentos determinantes dessa tessitura. ${ }^{1}$ Mas cabe ao menos notar que, se na obra de Platão não encontramos uma teoria do conhecimento no sentido estrito em que esta pode ser reconhecida, por exemplo, nas obras de René Descartes ou David Hume, nela encontramos ao menos um texto que dá uma atenção privilegiada aos problemas do conhecimento. Trata-se do Teeteto. Nele, a natureza mesma do conhecimento é colocada em questão. Como não pretendo deter-me aqui nos detalhes da problematização platônica, limito-me a apontar para os dois planos em que naquele diálogo Platão desenvolve, sucessivamente, sua análise epistemológica.

No primeiro plano, o problema da natureza do conhecimento é disposto enquanto algo que diz respeito à correção das sensações. Articulado pela via de uma discussão com Protágoras e Heráclito, Platão propõe, contra ambos, que o conhecimento envolve forçosamente a verdade como uma de suas condições necessárias e, por isso mesmo, deve ser concebido como algo que não pode estar sujeito a interpretações essencialmente diversas. É que, sustenta ele, tampouco o pode a verdade.

No segundo patamar de sua análise, Platão propõe que o conhecimento, em vez de ser investigado nos termos da mera sensação, o seja como algo que diz respeito ao que se pensa acerca daquilo que a sensação apresenta. A indagação epistemológica é então entendida como uma discussão sobre a opinião e, desde aí, o conhecimento é identificado inicialmente com a opinião verdadeira e, por fim, com a opinião verdadeira explicada. ${ }^{2}$

1 Vale mencionar, de todo modo, que tais ligamentos podem ser encontrados em alguns dos mais importantes diálogos platônicos. Talvez as passagens fundamentais sejam A República $\left(473^{\mathrm{d}}\right.$ e $476^{\mathrm{b}}$ $480^{\mathrm{a}}$ ), Mênon (em especial a sua parte final, com a famosa alegoria do Caminho para Larissa) e Teeteto (particularmente as passagens $151^{\mathrm{e}}-183^{\mathrm{c}}, 187^{\mathrm{b}}, 201^{\mathrm{d}}$ e $208^{\mathrm{de}}$ ).

É somente nesse segundo momento do texto que Platão dá início a uma análise que hoje reconheceríamos como sendo propriamente epistemológica. Até então, o texto platônico diz respeito mais especificamente a problemas metafísicos. Porém, já o referi, a ligação entre metafísica e teoria do conhecimento é aqui estreita e freqüentemente indistinguível, de modo que se correria o risco de romper uma das linhas de transmissão principais da argumentação do autor se fizermos aqui uma incisão demasiado profunda. 
Não obstante o próprio Platão, ao final do Teeteto, renunciar a essa definição, ela pode ser usada para descrever adequadamente o significado do termo "conhecimento', tal como o entenderam os grandes filósofos da tradição ocidental. ${ }^{3}$ Assim, atualizando a terminologia, podemos dizer que, desde Platão, o conhecimento tem sido identificado com a crença verdadeira justificada. De acordo com esta definição, portanto, uma análise do conhecimento nos apresenta as seguintes condições individualmente necessárias e conjuntamente suficientes: 1) a verdade da proposição que é o conteúdo da crença; 2) a crença nessa proposição; 3) o fato de que o agente doxástico ${ }^{4}$ esteja justificado ao crer nessa proposição.

Devo fazer duas observações a respeito dessa definição de raiz platônica. Primeira: Em vez de apresentar essa definição como uma definição do conhecimento tout court, talvez seja mais adequado dizer que essa é a definição do termo 'conhecimento proposicional'. Ocorre que o termo 'conhecimento' pode ser utilizado num amplo leque de sentidos diferentes. Essa variada gama de sentidos é comumente enfeixada em três conjuntos básicos. Desse modo, quando se atribui conhecimento a uma pessoa, pode-se querer dizer que essa pessoa tem alguma habilidade - como em "Júlio sabe nadar" - ou que ela tem familiaridade com algum lugar ou pessoa - como em "Júlio conhece Florianópolis" - ou, enfim, que ela sabe que uma proposição é verdadeira - como em "Júlio sabe que Paris é a capital da França". Se esses três diferentes usos do termo 'conhecimento' podem ser unificados, é questão que permanece polêmica. ${ }^{5}$ Seja como for, o sentido que aqui interessa é aquele que ele tem quando é usado para fazer referência ao conhecimento de proposições - também chamado de 'conhecimento de verdades' ou de 'conhecimento de fatos'. Desse modo, toda referência feita ao longo deste trabalho ao conceito de conhecimento deve ser entendida como uma referência ao conceito de conhecimento proposicional.

Segunda: A insuficiência desse conjunto de condições para caracterizar o conhecimento foi exposta de forma irrefutável por Edmund Gettier num pequeno, porém já clássico, ensaio publicado em 1963 sob o título de Is justified true belief knowledge?. O reconhecimento dessa insuficiência e da conseqüente necessidade de complementar, ou de alguma maneira modificar, o conceito platônico ou tradicional de conhecimento gera um problema, o Problema de Gettier. Este se constitui, por si só, numa poderosa fonte de polêmicas no campo da Teoria do Conhecimento contemporânea. ${ }^{6}$ Não tratarei dele aqui. Não obstante sua relevância, ele não parece afetar o suposto de que a justificação é uma condição necessária para o conhecimento, e tudo a que me proponho neste artigo é abordar algumas das questões ligadas a essa exigência de justificação epistêmica.

3 Platão rejeita a definição por considerá-la circular. Diante disto, a análise platônica se detém.

4 A expressão 'agente doxástico' é a tradução usual na comunidade epistemológica do termo inglês 'believer'; embora a tradução literal que imediatamente se apresente seja simplesmente o termo 'crente', a conotação religiosa que a essa palavra imediatamente se associa na língua portuguesa sugere que este seja um dos casos em que a literalidade poderia prejudicar a compreensibilidade.

O uso alternativo dos verbos 'saber' e 'conhecer', de que me utilizei nos exemplos apresentados, é às vezes também associado aos diferentes significados básicos do termo 'conhecimento'. Esta questão,

. porém, é apenas uma das muitas a que, por várias razões, ao longo deste trabalho devo apenas aludir. A bibliografia acerca do tema é imensa; talvez um bom ponto de partida seja o verbete "Gettier problem" em (Dancy, Sosa, 1992). 


\subsection{Aristóteles e o problema da justificação}

Se os problemas relativos à definição do conhecimento nos remetem a Platão, as questões que dizem respeito à justificação como uma condição necessária do conhecimento encontram sua origem histórico-filosófica na obra de Aristóteles. Os Segundos analíticos, em particular, são reconhecidos como base do tradicionalmente chamado 'problema do regresso epistêmico' ou 'argumento do regresso epistêmico'. ' O argumento pode ser assim formulado: ${ }^{8}$ dada uma crença $x$ qualquer, a condição para que essa crença esteja justificada é a existência de uma segunda crença, y, que sirva como base para a justificação de x. Se, porém, descartarmos a hipótese de que uma crença não-justificada esteja apta para justificar qualquer outra crença, devemos exigir que essa segunda crença, y, encontre sua justificação numa terceira crença, $z .^{9}$ Assim desenhado o quadro da justificação, nos encontramos com três possibilidades lógicas para compreender a sua configuração mais ampla.

Uma possibilidade que imediatamente se apresenta é a de que a cadeia da justificação prossiga infinitamente; neste caso, porém, a crença $x$, crença para a qual inicialmente buscávamos justificação, permanecerá refém dessa infinitude. ${ }^{10}$ Uma segunda possibilidade é a de que a cadeia da justificação prossiga até alcançar uma crença de um tipo especial: uma crença que, embora esteja justificada, não esteja inferencialmente justificada. A idéia aqui é a de que esse recurso evita que sejamos remetidos para ainda outra crença, e então outra, e assim ad infinitum. Uma crença dotada de uma tal característica especial pode ser

\footnotetext{
De fato, a primeira formulação clara do problema deve ser atribuída a Sexto Empírico. O que Aristóteles sustenta é mais simplesmente que o conhecimento de tipo inferencial depende necessariamente de algum outro tipo de conhecimento - um conhecimento não-inferencial. Esta última idéia parece ser o núcleo essencial do argumento do regresso epistêmico, e é por esse motivo que o remeto a Aristóteles.

8 Formulações alternativas desse argumento podem ser encontradas em praticamente todas as obras que apresentam as teorias da justificação epistêmica. Para discussões sintéticas dele podem ser consultados os verbetes "Epistemic regress argument" e "Foundationalism" em Audi, 1999, e a introdução de Moser, 1986.

9 Ainda que a suposição de que somente crenças justificadas possam justificar outras crenças seja amplamente aceita, não há total consenso sobre a questão. Um exemplo de dissensão é a teoria contextualista de David Annis. Ainda que o contextualismo seja visto como ocupando apenas uma posição de segunda importância no debate epistemológico contemporâneo - e seja, com alguma freqüência, simplesmente ignorado como uma alternativa a ser considerada -, cabe ao menos notar que existem ao menos dois tipos de propostas que, em epistemologia, podem ser denominadas de contextualistas. A primeira delas pretende-se uma alternativa ao fundacionismo e ao coerentismo. O próprio Annis é seu mais notório proponente; em "A contextualist theory os epistemic justification" (1978, p. 203-213), ele traça os contornos de sua proposta e elabora respostas ao que supõe serem as principais objeções a ela. A segunda proposta contextualista traz como marca distintiva a pretensão de responder ou, ao menos, explicar as dificuldades e os paradoxos teóricos historicamente produzidos pelas hipóteses céticas. Associados a esta proposta, três nomes se destacam: Keith DeRose (1995), David Lewis (1996) e Stewart Cohen (1999).

10 A posição infinitista, entretanto, não carece de defensores. Para uma abordagem do tema, a referência obrigatória é Peter Klein (1999). Tito Flores (2004), em um recente trabalho, apresenta, desenvolve e, em alguma medida, critica a proposta de Klein.
} 
chamada de 'crença fundacional', já que ela desempenha o papel de fundamento sobre o qual se sustenta toda uma cadeia de crenças justificadas. 'Fundacionistas', por extensão, é como serão chamados os filósofos que assumem a existência de tais crenças não-inferencialmente justificadas. ${ }^{11}$

Há, enfim, uma terceira possibilidade: a cadeia da justificação pode terminar por revelar-se circular. Ou seja, pode ocorrer que, ao retrocedermos ao longo da série de inferências, encontremos que uma dada crença, $z$, que justifica $y$, que justifica $x$, seja ela própria justificada por $x$. Neste caso, não encontramos na cadeia da justificação crença alguma que não esteja justificada. E tampouco haverá aqui a necessidade de apelar para uma qualquer crença de natureza especial; vale dizer, não haverá aqui a necessidade de apelar para uma crença fundacional. Filósofos que assumem esse modelo de estrutura circular e rejeitam a existência de uma classe privilegiada de crenças justificadas de modo nãoinferencial são chamados de 'coerentistas', dado que uma tal estrutura circular é comumente entendida como constituindo um conjunto coerente. ${ }^{12}$

Nas páginas que se seguem, apresento e assumo a defesa de uma resposta coerentista ao problema do regresso. Concluo esta seção introdutória com duas observações importantes. Primeira: como se verá, a caracterização de uma teoria coerentista como comprometida com a circularidade tout court não é adequada. De toda maneira, sigo neste momento inicial a caracterização usual para, na seqüência, indicar a maneira de desarmá-la. Segunda: a proposta que defendo, ainda que tenha sido inspirada pelo trabalho de dois dos principais epistemólogos coerentistas contemporâneos - Laurence BonJour ${ }^{13}$ e Keith Lehrer -, é de minha inteira responsabilidade. A sustentação desta proposta se articula por meio de um conjunto de distinções traçadas a propósito do processo e da estrutura da justificação epistêmica. Na próxima seção, apresento aquela que é a mais elementar de tais distinções: a distinção entre a verdade e a justificação.

\section{Verdade e justificação: uma distinção indispensável}

Devo destacar que a teoria coerentista proposta neste trabalho é uma teoria coerentista da justificação epistêmica. Trato aqui exclusivamente, portanto, da condição de justificação exigida pelo conceito tradicional de conhecimento e de algumas implicações dessa condição. Nada direi, nas páginas que se seguem, a propósito da natureza da condição da verdade para o conhecimento.

11 Bertrand Russell, Roderick Chisholm e Paul K. Moser - para citar apenas alguns dentre muitos podem ser reconhecidos como fundacionistas.

2 Wilfrid Sellars, Laurence BonJour e Keith Lehrer são proponentes de alguma forma de coerentismo.

Há algum tempo que BonJour abandonou as trincheiras coerentistas. Não obstante, pela clareza das análises e pela honestidade em assumir as mais duras conseqüências de sua antiga teoria, ele influenciou muitos - inclusive ao autor deste trabalho. 
Ocorre que, embora diversos pensadores tenham, ao longo da história da Filosofia, sustentado conjuntamente uma teoria da justificação e uma teoria da verdade coerentistas - e isso, o mais das vezes, de uma forma tal que torna praticamente impossível distinguir onde termina uma e começa outra -, a distinção entre ambas é requisito não apenas de clareza e rigor conceitual, mas até mesmo da possibilidade de sustentação de certas versões do coerentismo. A demarcação entre, de um lado, uma teoria da verdade coerentista e, de outro, uma teoria da justificação coerentista, permite dispensar o compromisso com algumas suposições que podem revelar-se muito problemáticas (notoriamente, aquelas de caráter idealista e metafísico). ${ }^{14}$ Além disso, a clara delimitação teórica possibilita problematizarmos os supostos de cada um daqueles tipos de teoria de forma independente, com o que nossas análises ganham em precisão. Com isso, o tratamento das relações entre justificação e verdade (tratamento, de resto, indispensável) pode ser elaborado em um segundo e derivado momento. Abre-se com isso, ainda, a possibilidade de que uma teoria da justificação coerentista seja associada a uma teoria da verdade não-coerentista. ${ }^{15}$

Nada disso implica, devo destacar, ainda que com o risco de tornar-me óbvio, que a justificação e a verdade sejam estranhos entre si. Todo valor que possamos atribuir à justificação epistêmica parece estar na dependência direta do papel dessa justificação enquanto ferramenta de obtenção da verdade e, com ela, do conhecimento. Desse modo, a justificação epistêmica deve ser reconhecida sobretudo por seu aspecto instrumental e, embora neste trabalho ela seja tomada como o objeto privilegiado da investigação, ela não deveria ser considerada como um fim em si mesma. ${ }^{16}$

A melhor maneira de iluminar a relação entre verdade e justificação talvez seja tentando responder à pergunta "Por que buscamos a justificação epistêmica?". A elaboração de uma resposta a esta pergunta nos conduz diretamente à concepção tradicional do conhecimento, concepção essa que associa a justificação à crença e à verdade. É a justificação de crenças em proposições verdadeiras que, se não pode ser plenamente identificada com o conhecimento, parece ao menos poder ser assumida como o seu núcleo imprescindível. É a justificação que nos permite transitar entre o mero palpite feliz, fruto espontâneo e irresponsável da mente, e a reconhecidamente sólida veracidade, como quer que esta seja adicionalmente caracterizada. Laurence BonJour formula essa idéia da seguinte maneira:

14 Apontar essa vantagem de uma clara distinção entre verdade e justificação não implica em afirmar, porém, que não haveria qualquer vantagem em assumir uma teoria da justificação e uma teoria da verdade correlativas. Para uma breve exposição de tal vantagem, veja Kirkham (2003, seção 7.1). Para uma amostra das possibilidades postas por um tipo de abordagem diferente da que escolhemos aqui, veja também Davidson (1990).

15 Esse é justamente o caminho escolhido por Laurence BonJour. Ao mesmo tempo em que defende uma posição coerentista a propósito das teorias da justificação epistêmica, ele assume a tradicional teoria da verdade correspondencial.

16 É quase desnecessário dizer que tampouco sobre este ponto encontramos consenso. Para apreciar um ponto de vista divergente e muito influente, veja Foley (1993). 
A característica distintiva da justificação epistêmica é, assim, sua relação interna ou essencial com a meta cognitiva da verdade. Segue-se que os empreendimentos cognitivos de uma pessoa estão epistemicamente justificados apenas se, e na extensão em que, eles alvejam essa meta, o que significa, grosso modo, que se aceita todas e apenas aquelas crenças que se tem boa razão para pensar que são verdadeiras (BonJour, 1985, p. 8). ${ }^{17}$

Assim descrita a meta epistêmica, ela articula numa única e mesma formulação um alvo que, talvez convenha lembrar, é, de fato, duplo. Trata-se, com efeito, da conjunção de duas metas distintas embora complementares: é somente na medida em que funciona simultaneamente como uma ferramenta para a aquisição de verdades e para a exclusão de falsidades que a justificação cumpre plenamente seu papel epistêmico. ${ }^{18}$

Temos assim que, se de um lado a condição epistêmica da justificação deve ser concebida como indispensavelmente conectada com a condição epistêmica da verdade; de outro, é igualmente indispensável que evitemos a simples indistinção entre ambas. Num caso, a confusão entre ambas as condições, mesmo quando não condena em definitivo todo o esforço de elucidação de cada uma delas, ao menos compromete em alguma medida a busca de clareza e de rigor que deveria caracterizar toda análise filosófica. Noutro, a desconexão de justificação e verdade, mesmo quando não torna simplesmente incompreensível a própria noção de justificação no sentido em que aqui nos interessa, compromete a distinção entre os vários sentidos possíveis do termo 'justificação'.

Para ver como isso poderia ocorrer, basta considerar as múltiplas possibilidades de caracterização da justificação. Muitas vezes o uso do termo 'justificação' indica que ele está sendo empregado em um sentido nitidamente distinto daquele que o caracteriza quando o relacionamos com a busca da verdade (e com a esquiva da falsidade). É o caso, por exemplo, da justificação posta a serviço de objetivos pragmáticos, tais como a esperança de sobrevivência em condições extremamente adversas. Em tais circunstâncias, não é raro que uma crença em proposições (provavelmente) falsas esteja justificada no sentido de que essa crença aumenta, em alguma medida, as chances de superar as adversidades. Tais formas de justificação, formas que não trabalham em função do conhecimento, são costumeiramente chamadas de 'prudenciais' ou 'pragmáti-

É minha a tradução desta e das outras citações encontradas neste artigo.

Se houver dúvidas a esse respeito, talvez baste considerar o quanto se afastariam de um semelhante ideal epistêmico, seja uma pessoa que (por ingênua e dotada de boa-fé em um nível quasepatológico) cresse em qualquer proposição que lhe fosse apresentada, seja uma outra que, na situação antípoda, negasse assentimento a toda proposição com a qual se deparasse. Não obstante o ingênuo do primeiro exemplo cumprir com perfeição a meta de crer em proposições verdadeiras pois ele crê em todas as proposições e, portanto, também em todas as proposiç̃es verdadeiras que encontra -, ele acreditará também num grande número de proposições falsas. O descrente do segundo exemplo, por sua vez, é exemplar na satisfação do objetivo de evitar crer em proposições falsas, mas seu fracasso epistêmico não é menos retumbante, uma vez que não encontraremos quaisquer crenças verdadeiras em seu sistema doxástico - de fato, por suposição, não encontraremos ali quaisquer crenças. 
cas'. ${ }^{19}$ Essas outras formas de justificação, quaisquer que seja sua relevância desde outros pontos de vista, não serão abordadas aqui. Ocupar-me-ei exclusivamente com a justificação epistêmica.

Feita essa indispensável distinção entre verdade e justificação epistêmica, volto-me agora para o problema da estrutura da justificação epistêmica. Este problema, já destaquei, é colocado em relevo pelo argumento do regresso epistêmico. Quando antes indiquei, de maneira esquemática e preliminar, qual é a solução coerentista para o problema do regresso, um aspecto muito pouco razoável desta solução terá se destacado mesmo aos olhos do leitor menos atento. Com efeito, o problema do regresso epistêmico parece comprometer a sua solução coerentista com a circularidade lógica, circularidade viciosa que ameaça corroer a base mesma de uma tal proposta. Na próxima seção, tento analisar mais detidamente a natureza dessa ameaça.

\section{Circularidade: por que ela é viciosa?}

Antes de tratar do problema que esta seção coloca, devo dizer algumas palavras preliminares acerca do conceito de coerência. Seria de se esperar, dada a óbvia centralidade que este conceito tem em qualquer versão do coerentismo, que ele fosse alvo de uma atenção privilegiada por parte dos autores coerentistas. Surpreendentemente, porém, isto não acontece. Ao invés, o procedimento mais comum é o desenvolvimento das diversas teorias desde a suposição de que todos temos uma compreensão intuitiva do significado do termo 'coerência' e de que essa compreensão seja de algum modo suficiente. ${ }^{20}$ Não pretendo nem posso agir diferentemente aqui, mas gostaria de, ao menos, indicar as duas condições que considero fundamentais para que um sistema seja considerado coerente.

A primeira delas é a consistência do sistema. Esta condição é por si só insuficiente para caracterizar a coerência de um sistema, já que ela apenas indica o tipo de infração que não deve ser permitido: nenhum sistema que contenha $p$ e, adicionalmente, $\sim p$, deve ser considerado coerente. É necessário acrescentar um critério de avaliação positivo. Daí por que também deveríamos exigir que um sistema coerente fosse avaliado em função das relações inferenciais segundo as quais seus elementos componentes são articulados.

19 Além do sentido pragmático, o termo 'justificação' também pode ser utilizado em outros sentidos por exemplo, atribuindo a justificação a ações ou a decisões em vez de atribuí-la a crenças.

Laurence BonJour (1985), por exemplo, se utiliza da singular premissa de que a coerência é, no fim das contas, um ingrediente importante de qualquer teoria da justificação epistêmica, para concluir que uma análise do conceito de coerência não deve ser considerada como a tarefa privilegiada do coerentismo. Uma tal afirmação deve ser relativizada: vejo-a, antes de tudo, como uma advertência de que a descrição da estrutura de um sistema coerente não é simples de obter e de que se nos satisfizermos - ao menos provisoriamente - com uma análise esquemática da coerência, isso não compromete de antemão a articulação de uma teoria da justificação epistêmica coerentista. Tampouco BonJour se recusa a apresentar uma análise do conceito de coerência. 
Essas relações podem ser consideradas desde vários aspectos. Por exemplo, um sistema com maior quantidade de ligações inferenciais entre seus componentes pode, em princípio, ser dito mais coerente do que um sistema que seja articulado por um menor número de tais ligações. De outro lado, não é apenas a quantidade, mas também a qualidade das relações de inferência que deve entrar na avaliação da coerência do sistema. É certamente possível que um sistema que contenha um pequeno número de conexões de inferência seja mais coerente, devido à natureza particularmente forte dessas conexões, do que um sistema que contenha um grande número de tais conexões. Mas não prossigo nesta discussão. Para a apresentação da proposta que se segue, bastará a idéia de que a consistência e a conectividade inferencial são os dois fatores elementares desde os quais um determinado sistema coerente deve poder ser avaliado. E isto é tudo o que direi aqui sobre a natureza da coerência. ${ }^{21}$ Passo imediatamente ao problema da circularidade.

Consideremos o caso mais simples de circularidade, a saber, aquele em que uma proposição $p$ qualquer é oferecida (seja de forma explícita ou implícita), simultaneamente, como premissa e conclusão de um argumento. Notemos, de início, que um argumento é estruturado justamente para tentar estabelecer - de maneira necessária ou dedutivamente, de maneira provável ou indutivamente - a verdade de sua conclusão. Um argumento cuja verdade da conclusão não esteja em questão parece ser um argumento inútil, pois se propõe à tarefa de estabelecer o que já está estabelecido. Se este não é o caso, mas, ao invés, a verdade da conclusão está em questão, então é a suposição indevida da sua verdade que é problemática. Em outras palavras, a oferta de $p$ como premissa de si mesma é inútil; e este é o grande problema com um raciocínio e uma justificação circulares.

Trata-se assim de que, ao fazer o trânsito da premissa $p$ para a conclusão $p$, percorro um caminho que é circular e, desse modo, termino onde comecei. Como terei me engajado num processo inferencial em primeiro lugar porque não queria ficar onde estava - isto é, porque, supostamente, eu alimentava dúvidas acerca da verdade de $p$ e buscava de alguma maneira dissipar tais dúvidas -, resulta que meu engajamento terá sido em vão. Acabar no mesmo lugar donde parti deve ser reconhecido como um fracasso em atingir a justificação. É um fracasso, portanto, que diz respeito à minha trajetória doxástica. Considere a propósito o esquema seguinte (neste esquema, $p, q, r$ e $s$ representam proposições e o símbolo $\rightarrow$ indica uma relação inferencial):

21 Ou quase tudo. Observe que trato a coerência como uma característica de determinados sistemas. Há, porém, um problema com semelhante procedimento. Ocorre que a caracterização da coerência desde essa consideração sistemática provavelmente nos exige demasiado. Com efeito, se o que torna as crenças coerentes é a sua inserção em um sistema dotado de certas propriedades, então é a consideração desse sistema que se torna proeminente. Mas não parece em absoluto ser o caso de que o sistema doxástico esteja assim na berlinda numa situação típica em que estamos justificados em crer numa proposição qualquer. Em outras palavras, não se trata, o mais das vezes, do problema de termos ou não um sistema doxástico coerente, mas de termos ou não uma crença que é coerente com nosso sistema doxástico. Este problema será ignorado aqui. 
Esquema 1

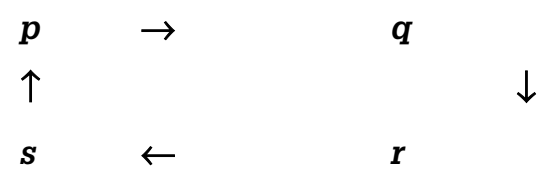

Se o que o coerentismo defende é que o processo de justificação epistêmica seja algo semelhante ao que o esquema acima representa, denunciam seus críticos, ele não passa de um banal equívoco. É essa banalidade que se refugia, quiçá, numa lógica embaraçada ou numa retórica sutil. Como podemos responder a isso? Bem, a primeira resposta é assumir que ela está simplesmente correta. Se for tal coisa que o coerentista sustenta, não importa de que recursos retóricos ele se utilize ou de que aparatos lógicos ele se valha: ele está claramente equivocado. Não obstante, quero agora considerar um caso no qual a crença de que $p$ esteja justificada por um sistema doxástico composto por crenças em, digamos, outras cinco proposições, $q, r, s, t$ e $u$. Neste caso, iríamos nos deparar com uma estrutura inferencial que se pareceria com a seguinte:

Esquema 2

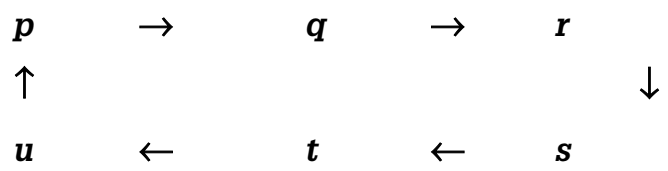

Há pouco condenamos sumariamente uma estrutura muito semelhante. Porém, tínhamos o direito de fazê-lo? Bem, talvez não sumariamente. Senão, consideremos a peça acusatória: qualquer estrutura inferencial que assuma a circularidade comete uma falácia de petitio principii e, assim, desqualifica qualquer sustentação que pudéssemos ter produzido. As evidências que sustentam esta acusação são avassaladoras. Que defesa poderia ser alegada frente tão grave delito lógico? Bem, talvez possamos apelar às circunstâncias atenuantes do caso. Repare que o Esquema 2 acima inclui seis proposições. Duas a mais, portanto - $t$ e $u-$, do que as que encontramos no Esquema 1. Será razoável afirmar que isso não faz qualquer diferença? Não deveríamos tratar uma estrutura inferencial composta por seis proposições de maneira diferente daquela como tratamos uma estrutura composta por apenas quatro proposições?

A resposta, claro, será que isso não faz qualquer diferença porque é de inferencialidade que se trata. Ou seja, se toda razão que temos para pensar que $p$ é verdadeira é que $q$ é verdadeira, toda a razão que temos para pensar que $q$ é verdadeira é que $r$ é verdadeira, toda a razão para pensar que $r$ é verdadeira é que $s$ é verdadeira e, finalmente - no caso do Esquema 1 -, toda a razão que temos para pensar que $s$ é verdadeira é que $p$ é verdadeira, então, ao fim e ao cabo, toda a razão que temos para pensar que $p$ é verdadeira é que $p$ é verdadeira. 
Ora, mas se temos alguma evidência (independente) sobre a verdade de $p$, por que nos envolvemos em um semelhante processo argumentativo em primeiro lugar? E, se não temos tal evidência (independente), que sentido faria apelar para a verdade de uma proposição que, justamente e desde o início, está em jogo? Em qualquer caso, aumentar o número de elos da cadeia argumentativa não trará benefícios em termos de justificação. O Esquema 2 sofre do mesmo defeito e é, por isso mesmo, igualmente condenável. E de fato, como o argumento do regresso já antes indicou, qualquer esquema semelhante, não importa qual seja a quantidade de seus componentes, será igualmente condenável. Apelo negado, e caso encerrado!

E se, porém, não pensarmos em inferências? E se pensarmos antes nas relações de articulação mútua que se estabelecem entre as proposições que são o objeto das minhas crenças como um caso que não se regula por articulações inferenciais? Neste caso, a circunstância de que meu sistema doxástico seja integrado por quatro, seis, ou mais crenças, talvez possa, afinal, fazer alguma diferença. Mas que tipo de relações seriam essas? Para adiantar uma idéia do tipo de articulação que poderia estar em jogo aqui, ofereço uma ilustração.

Deixemos, a título de exemplo, que $p$ seja uma das conhecidas proposições apresentadas por Moore como casos de conhecimento e consideremos, digamos, a crença na proposição de que "A terra existiu durante muitos anos passados". ${ }^{2}$ O que me justifica a crer nesta proposição? Outras crenças, muitas outras crenças: crenças sobre minha própria finitude e meu lugar insignificante na grande ordem das coisas, para começar. E o que justifica tais crenças sobre esse meu status inferior na cena cósmica? Uma resposta é que a crença de que "A terra existiu durante muitos anos passados" as justifica. Eis aí um círculo. Temos também aqui um círculo vicioso? Não é o que parece. Ao invés, que tais crenças se relacionem dessa maneira parece antes sustentá-las mutuamente do que de qualquer modo condená-las. E, neste caso, também a quantidade de crenças que formam meu sistema doxástico fará diferença. Pequenos conjuntos de crenças são frágeis; conjuntos vastos são sólidos.

Naturalmente, não é possível que seja apenas e tão-somente o número de crenças que integram um sistema doxástico que determine a solidez deste sistema. Um caos doxástico não perde seu caráter caótico simplesmente por ser ampliado. Mais do que o mero número de crenças, são as relações de sustentação recíproca que elas articulam entre si que irão determinar o vigor do sistema doxástico.

22 Essa é uma das várias proposições que, em Uma defesa do senso comum, George Moore sustenta serem objeto de conhecimento. Diz ele a respeito de tais proposições:

"Não é possível que simplesmente acredite nelas? Ou que eu saiba que elas são altamente prováveis? Ao responder a esta questão, penso não ter nada melhor do que dizer que me parece conhecê-las com certeza. É, entretanto, óbvio que, no caso de muitas delas, não as conheço diretamente: o que quer dizer somente que conheço porque, no passado, soube que eram verdadeiras outras proposições que eram evidência para elas. Se, por exemplo, sei que a terra existiu durante muitos anos antes de eu ter nascido, com certeza sei isto porque sabia outras coisas no passado que eram evidência para ela. E certamente não sei qual era a evidência. Entretanto tudo isso não me parece ser uma boa razão para duvidar de que a sei" (Moore, 1989, p. 252). 
Que relações são essas e como elas podem desempenhar um semelhante papel ${ }^{23}$ Um coerentista não pode abrir mão de tentar responder a isto. Na próxima seção, tento apresentar algumas idéias que podem se revelar de algum interesse para produzirmos uma resposta razoável a essa questão.

\section{Justificação linear e justificação sistêmica}

\subsection{Metáforas}

Quero discutir aqui uma idéia que o problema do regresso epistêmico assume como pressuposto aparentemente indisputável: trata-se da idéia de que toda justificação estrutura-se, ao fim e ao cabo, de forma linear. Tal como é original e tradicionalmente apresentado, o problema do regresso epistêmico destaca a natureza linear da estrutura da justificação epistêmica. Uma maneira de lidar com essa situação é trazer à luz do debate tal pressuposto e indicar como ele formata o problema do regresso e como ele determina que as respostas alternativas a este problema sejam apenas e exatamente aquelas que antes apresentei.

O coerentismo não está disposto a assumir o pressuposto de que justificação e linearidade sejam inseparáveis. Para ver como essa recusa pode ser articulada, podemos começar com um renovado olhar sobre a tradicional metáfora que apresenta a estrutura da justificação como uma cadeia de crenças. A idéia é considerar mais atentamente a metáfora e ver se ela não poderia ser utilizada para conduzir a análise numa direção distinta. ${ }^{24} \mathrm{~A}$ metáfora da justificação como uma cadeia composta por elos doxásticos impõe-se com naturalidade pela maneira mesma como o problema do regresso é apresentado. Falamos, desde o princípio, numa cadeia da justificação cujos elos são crenças que se engatam umas nas outras; como não pensar em seguida na imagem usual de uma corrente que deve estar ancorada em uma base segura?

Lembremos, no entanto, que uma corrente não precisa necessariamente estar presa em alguma base específica para cumprir a sua função de amarração. Claro, uma pequena e leve corrente é, em geral, inútil para desempenhar essa função se ela não estiver fixada em algum ponto. Mas pensemos em uma corrente muito grande e muito pesada. Se ela tiver uma envergadura suficiente, não será necessário ancorá-la em lugar algum para que ela sirva a seu propósito; o seu próprio peso - ou talvez a sua inércia - proporcionará a ancoragem necessária (o peso ou a inércia necessários deverão ser considerados em função daquilo a que deve a cadeia sustentar). De maneira equivalente, podemos pensar numa cadeia justifica-

23 Cabe lembrar que tais relações só importam na extensão em que elas tiverem uma função relevante em termos de justificação epistêmica, vale dizer, nada importam aqui quaisquer relações que caracterizem crenças e que de algum modo as articulem, mas que não as vinculem à (provável) verdade das proposições em que cremos.

24 Para isto servem, afinal, as metáforas em filosofia. E esta não é uma serventia desprezível. Sem equívocos, porém: o que está em jogo aqui é mais do que a mera escolha - equivocada ou não - de uma determinada metáfora. 
tória enquanto sustentada por seu próprio "peso" ou mantida fixa pela sua própria "inércia". A idéia que esta imagem sugere - me sugere, em todo o caso - é a de que o encadeamento de um grande número de elos doxásticos poderia de algum modo produzir, no campo da justificação epistêmica, um resultado equivalente àquele que o encadeamento de um grande número de elos materiais pode produzir em relação à fixação de objetos físicos.

O ponto a ser destacado aqui, portanto - e para o qual a extrapolação da metáfora nos serve -, é que a justificação talvez cumpra sua função epistêmica graças à ligadura que lhe dá a coerência das crenças. Assim, enquanto que os elos doxásticos individuais engatam-se linearmente, o que garante que a cadeia da justificação cumpra sua função é a articulação inteira dessa cadeia. Essa articulação pode ser vista como sustentada pelo sistema doxástico como um todo. Assim, se a metáfora pode ser razoavelmente estendida de modo a abranger a ilustração que sugeri - e não vejo por que ela não o possa -, então estaremos agora olhando para a justificação epistêmica desde uma perspectiva segundo a qual o tamanho e a força do conjunto inteiro de nossas crenças faz diferença. Com efeito, desde esse ponto de vista há uma diferença relevante entre o Esquema 1 e o Esquema 2 que apresentei na seção anterior. E essa relevância é uma relevância epistêmica.

Supondo que a força das ligações inferenciais representadas pelos Esquemas 1 e 2 sejam idênticas, podemos agora também assumir que, digamos, a proposição $p$ está mais bem justificada no Esquema 2 do que no Esquema 1, exatamente porque o Esquema 2 contém um conjunto maior de proposições e essa superioridade no número de proposições componentes em relação ao Esquema 1 lhe confere também uma superioridade epistêmica. Desde esta perspectiva, a força de toda a cadeia da justificação não depende apenas da força justificatória de cada um de seus elos tomados individualmente. Ao invés, quando adotamos uma perspectiva sistêmica, temos que a força justificatória do conjunto inteiro é uma resultante da ação de todas as ligações individuais e tem, portanto, a força que o conjunto produz na exata medida em que ele constitui um conjunto. Como conseqüência, podemos assumir dois pontos de vista distintos e complementares: desde o ponto de vista linear, a força da cadeia justificatória como um todo não ultrapassa a força do mais fraco de seus elos; do ponto de vista sistêmico, porém, a força da cadeia justificatória deve ser avaliada desde a combinatória de seus elos. Ou assim o sugere a extrapolação da metáfora da estrutura da justificação como uma cadeia de elos doxásticos.

Mas não é à metáfora - ou, pelo menos, não é apenas a ela - que precisamos nos remeter se quisermos evitar a implicação de que alguma versão do fundacionismo precisa ser assumida. Ocorre que o coerentismo contemporâneo tem sido tão perdulário em metáforas acerca da compreensão coerentista da justificação, quanto avarento em seus argumentos. Assim, a estrutura da justificação já foi representada como uma jangada e como uma rede e tais imagens continuam ainda a circular quando se trata de apresentar a perspectiva coerentista. Claro está, não há nada de particularmente errado nas metáforas; de fato, mais de um filósofo já salientou a importância e a força das metáforas para a sustentação de uma 
determinada teoria filosófica ou científica. O problema ocorre quando as metáforas substituem os argumentos, quando aquelas se colocam no lugar destes ou mesmo obstruem a estruturação de uma argumentação adequada para uma teoria. Embora aquelas imagens intuitivamente penetrantes pareçam dar sugestões promissoras a propósito de uma compreensão da justificação, como regra tais promessas não são cumpridas. Este é o ponto em que, em geral, a prodigalidade dá lugar à avareza e as imagens substituem pobremente os argumentos. Na seqüência, gostaria de ajudar a remediar esta situação.

\subsection{Justificação sistêmica}

Que o pressuposto da necessária linearidade da justificação determine as respostas tradicionalmente reconhecidas para o problema do regresso epistêmico parece inquestionável. Poder-se-ia argumentar, claro, que esse pressuposto constitui tal problema de maneira essencial e indispensável e que recusá-lo é recusar a própria questão que ele nos propõe. Mas por que seria assim?

Ocorre que, se, por um lado, é verdade que o pressuposto de que toda justificação seja linear determina a forma característica como é apresentado o argumento do regresso, de outro, não parece que negar esse pressuposto adultere o problema colocado pelo argumento. Antes, o contrário: livrar o argumento da confusão entre linearidade e justificação talvez nos permita descartar um adventício desarrazoado que desde há muito mascara o leque das respostas que ele realmente comporta. Não descaracterizamos com isto a questão substancial que ele coloca, já que não estamos abandonando a busca da compreensão da estrutura da justificação. Assim, assumindo que o coerentismo não nega uma resposta ao problema do regresso nem o equaciona indevidamente, posso precisar o que entendo por justificação sistêmica.

Começo pelo óbvio: quando ordinariamente construímos argumentos e fazemos inferências, tais argumentos e inferências têm um aspecto evidentemente linear. Apresentamos proposições para justificar outras proposições, reunimos conjuntos de premissas para justificar conclusões. O caráter linear de tais estruturas faz parte de nossa experiência quotidiana e não haveria como ou por que negá-lo. Diferentemente surgem as coisas, porém, quando ampliamos nosso horizonte teórico e tentamos apreender a estrutura de grandes sistemas de crenças. Ou assim pensam os coerentistas.

Ilustrado brilhantemente pelo argumento do regresso epistêmico, o ponto de vista fundacionista a esse respeito é inequívoco: qualquer que seja a escala que adotarmos, a configuração da estrutura da justificação permanece inalterada: uma vez linear, sempre linear. Mesmo tomando em perspectiva a totalidade de um sistema doxástico, essa aparência não se altera. Do ponto de vista coerentista, porém, uma tal mudança faz toda a diferença. Enquanto fragmentária e parcialmente tomada, a justificação se afigura linear; do ponto de vista sistêmico, entretanto, a justificação assume um aspecto diferente. Nesta escala, a linearidade da justificação se revela como uma ilusão provocada pela pequenez da amostra ini- 
cialmente considerada e pela demasiada proximidade de nossa perspectiva ordinária. Essa perspectiva toma por objeto apenas fragmentos limitados de nosso sistema de crenças; ela pode fazê-lo, entrementes, apenas porque assume, como já antecipadamente estabelecida, uma articulação doxástica global.

Numa justificação de tipo linear são inferências que consideramos, e uma inferência se apresenta como uma estrutura assimétrica na qual (para ficarmos com o caso mais simples) uma crença de que $p$ justifica uma crença de que $q$. Neste caso, a crença de que $p$ está em um estrato lógico e epistêmico diferente daquele em que se encontra a crença de que q. Esta última depende, para sua sustentação, daquela primeira; mas o contrário não necessariamente ocorre. Se assumirmos que esta seja uma descrição satisfatória desta extensão mínima de uma cadeia justificatória, podemos, em seguida, potencializá-la e aplicá-la à cadeia inteira? É isto o que sugere o fundacionismo e é também isto o que sugere o argumento do regresso. E é esta mesma sugestão que não deveríamos aceitar.

Embora do ponto de vista que isola aquela pequena fração da cadeia justificatória faça todo o sentido falar na posterioridade e na dependência da crença de que $q$ em relação à crença de que $p$, e embora também faça todo o sentido repetir esse exercício onde e quantas vezes o quisermos, esse sentido se perde quando é a articulação da cadeia justificatória inteira que nos interessa. Se tomarmos a justificação epistêmica em seu caráter global e disperso, ao invés de em seu caráter local e concentrado, deixa de ser razoável pensar num sistema doxástico como uma única longa série de crenças linearmente conectadas.

Pois ocorre que, quer pensemos em teorias científicas complexas, quer pensemos apenas nas crenças que se entretecem e nos acompanham ao longo de todas as nossas pequenas tarefas cotidianas, não é por meio de uma seqüência doxástica linear que pensamos o mundo ou a nós mesmos. As articulações lineares que encontramos no primeiro e mais detalhado olhar se revelam fragmentos que se integram sistemicamente através de complexas relações de interdependência. Integração e sistematização essas que, justamente, proporcionam a sustentação de cada crença justificada em particular.

Não é o caso de recusarmos assimetria ao sistema doxástico. A justificação epistêmica exige assimetria. É na relação entre o sistema e as crenças particulares, entretanto, que essa assimetria será, em última instância, identificada. A assimetria epistêmica que um olhar pontual encontra na conexão inferencial entre a crença de que $p$ e a crença de que $q$ não é senão a extremidade mais visível dessa outra assimetria mais ampla e mais fundamental entre cada uma dessas crenças e o sistema doxástico no qual elas se articulam.

Se esta descrição é correta, então podemos dizer que acontece com a justificação epistêmica algo semelhante ao que ocorre em nossa experiência quotidiana do mundo físico. Em pequena escala e para todos os fins práticos assumidos em nossos afazeres comuns, podemos considerar a superfície de nosso mundo como plana; quando, porém, queremos relacionar o nosso sítio familiar com outros sítios, quando queremos compreender conjuntamente todos os sítios terrestres, uma constatação muito diferente se impõe. Globalmente considerado, nosso mundo, 
decididamente, não é um plano. Assim também acontece em termos de justificação epistêmica. Em contextos ordinários, a justificação aparece como eminentemente linear: justificamos nossas crenças particulares a partir de outras crenças particulares. Se alargarmos nossa perspectiva, entretanto, não nos deparamos contrariamente ao que sugere o argumento do regresso - com uma estrutura na qual crenças ligam-se umas às outras como elos de uma cadeia. Deparamo-nos, ao invés, com uma estrutura doxástica de caráter sistêmico. Ao considerarmos a justificação epistêmica com suficiente abrangência, a aparente e viciosa circularidade da justificação se revela uma ilusão criada por uma perspectiva demasiado limitada da estrutura da justificação.

\section{Justificação epistêmica: ela se move?}

É à escala global e ao aspecto sistêmico da justificação, parece-me, que Laurence BonJour se refere quando desenvolve a sua própria recusa do modelo da justificação epistêmica assumido pelo argumento do regresso. Diz ele a esse propósito:

A premissa tácita nessa aparentemente devastadora linha de argumento é a idéia de que a justificação inferencial é essencialmente de caráter linear, envolvendo uma seqüência linear de crenças ao longo das quais a justificação é transmitida das primeiras crenças da seqüência para as últimas crenças por meio de conexões de inferência. É esta concepção linear da justificação inferencial que em última instância gera o problema do regresso. Se ela é aceita, a idéia de que a justificação se move em um círculo será obviamente inaceitável [...] Assim, a resposta básica [...] ao problema do regresso não é o apelo a circularidade, que seria fútil por si só, mas antes a rejeição da concepção linear da justificação inferencial (BonJour, 1986, p. 120).

Como esta passagem indica, ao invés de pensar a justificação, como eu próprio o fiz, em termos do par linearidade/sistematicidade, BonJour sugere que a distinção seja feita em termos de inferencialidade linear/inferencialidade nãolinear. Será a diferença entre ambas as distinções simplesmente terminológica? Penso que não. Colocarei agora em foco as diferenças que as separam e o farei me valendo de uma crítica da noção de justificação inferencial não-linear, elaborada por Timothy Joseph Day. ${ }^{25}$ Com este procedimento, pretendo alcançar dois objetivos. O primeiro e mais imediato é destacar a vantagem da maneira como eu próprio tracei a distinção sobre a maneira como BonJour a fez. O segundo e mais importante objetivo é preparar o terreno para a apresentação da distinção entre justificação proposicional e justificação doxástica, distinção esta que introduzirei na próxima seção e que, argumentarei, é indispensável para a articulação satisfatória da proposta coerentista defendida.

Considere a seguinte observação de Timothy Day:

25 A crítica é desenvolvida no artigo "Circularity, non-linear justification and holistic coherentism", em Bender (1989, p. 134-141). 
A linearidade é um problema na medida em que nós pensarmos nas inferências como transmitindo justificação. Não há perigo de justificação circular na visão coerentista das coisas. Os únicos círculos aqui envolvem as conexões inferenciais entre crenças. Se nós começarmos com a crença A e avançarmos pelo sistema nós eventualmente voltaremos até A. Mas a conclusão disto tudo não é que A está justificado se A está justificado. A conclusão é, antes, que A é um membro de um sistema coerente (Day, 1989, p. 139-140)

Se interpreto bem esta passagem, ela sustenta que a idéia mesma de justificação inferencial não-linear está equivocada. Seu autor pensa talvez que a idéia heterodoxa de justificação que BonJour pretende defender com a noção de uma justificação inferencial não-linear poderia ser mais bem colocada nestes outros termos: deveríamos, primeiro, simplesmente admitir que a justificação, quando pensada como um processo pelo qual justificamos certas crenças a partir de certas outras crenças, tem uma natureza inferencial e linear: e, segundo, não deveríamos pensar na justificação em tais termos processuais - ao invés, deveríamos pensar nela em termos estruturais. Tal como o interpreto, portanto, Day está destacando que a análise da estrutura da justificação epistêmica não deveria ser confundida com a análise do processo da justificação epistêmica.

A idéia que embasa esta proposta parece ser a de que, uma vez que a coerência do sistema doxástico seja ela própria pensada como a fonte donde toda justificação emerge, as relações inferenciais poderiam ser deixadas em paz em toda sua linearidade. Também do ponto de vista de Day, assim como do ponto de vista de BonJour (e, claro, de meu próprio ponto de vista), a acusação de que a justificação se move em círculos não é uma acusação procedente. A estratégia de resposta a esta acusação patrocinada por Day parece basear-se na idéia de que os coerentistas não estão apresentando uma teoria do processo de justificação - e, por extensão, não estão defendendo uma teoria que assume a circularidade desse processo - mas, ao invés, estão apresentando uma teoria da estrutura da justificação. E não há nenhum problema óbvio em assumir que esta estrutura, ao invés desse processo, seja circular. Assim, em lugar de tentar negar a circularidade propondo um caminho alternativo não-linear para a justificação, seria melhor assumir um ponto de vista desde o qual a justificação simplesmente não se move ponto de vista desde o qual, portanto, ela não se move em círculos.

Creio que seja tanto possível quanto necessário traçar uma distinção entre a estrutura e o processo da justificação epistêmica. Mas não creio que a distinção deva ser traçada da maneira que Timothy Day o faz. Isso porque há problemas, parece-me, com a proposta que ele contrapõe à de BonJour. O mais importante de tais problemas é que, ao contrário do que ele sugere, um sistema doxástico coerente ou não - tem antes um caráter dinâmico do que estático. Para ver a relevância disto, considere o que segue.

Um sistema doxástico deve responder às mudanças e aos desafios a que o seu entorno normalmente o submete. Se for assim, ele deveria ser pensado como um sistema em constante renovação, sistema no qual não mais do que uma provisória estabilidade é a cada vez obtida. Percepções, raciocínios e novas informa- 
ções afetam diferentes pessoas em diferentes ritmos, mas, ao menos na grande maioria dos casos, creio que podemos assumir existir um fluxo quase ininterrupto de crenças recém-chegadas que vêm requerer cidadania justificatória e que devem ser adequadamente articuladas no sistema doxástico. A estrutura que assim se constitui deve ser entendida, por isso mesmo, como uma estrutura com menores ou maiores partes em constante rearticulação. E manter a estabilidade e a coerência doxásticas num ambiente assim movediço é parte importante de nossa vida mental.

Em particular (voltando por um instante às metáforas), não parece que a distinção entre o processo e a estrutura da justificação seja mais bem concebida (como o indica Day na passagem citada) nos moldes da distinção entre as linhas de transmissão de força - a estrutura - e a energia que é transmitida por elas - a justificação. Nesta imagem, uma e outra coisa são claramente distintas, já que as linhas de transmissão não deixam de ser o que são e de ter a forma que têm mesmo quando a energia não circula por elas. Mas não é assim que a relação entre a estrutura e o processo da justificação epistêmica deveria ser pensada. A justificação, tomada numa perspectiva sistêmica, pode se parecer menos com uma corrente a percorrer linhas de força desde o centro gerador até o ponto de consumo e mais como um campo de força global pelo qual a energia transita de maneira contínua e relativamente ordenada. Neste caso, em alguma medida - e não pequena - é esse trânsito mesmo que constitui o campo. E assim também parece ocorrer com a justificação: em alguma medida - e não pequena - talvez seja o próprio processo de justificação epistêmica que constitua a sua estrutura.

Que Day não considere apropriadamente este aspecto da justificação, no entanto, não tira o mérito da crítica certeira e aparentemente mortal que ele dirige contra a noção de inferência não-linear proposta por BonJour. Pois desde o princípio não se vê muito bem como essa forma não-linear da inferência deveria ser compreendida. Uma coisa é contestar a pouco plausível imagem da estrutura da justificação enquanto uma longa cadeia doxástica. Mas, se as relações de suporte mútuo entre as crenças devem ser pensadas aos moldes da justificação inferencial, então a inferencialidade deveria ser pensada em termos de não-linearidade. E o problema é que não se vê como isso poderia ser feito. ${ }^{26}$

A coisa toda toma ares de um dilema, se supusermos, em seguida, que a única alternativa a essa obscura noção de inferência não-linear seja a proposta defendida por Day para responder à acusação de circularidade. Esta proposta, como tentei mostrar, pode ser caracterizada pela idéia de que a justificação não se move. E esta não parece ser uma idéia correta. Como ficamos, então?

${ }^{26}$ E, seja como for, o próprio BonJour não demorou a reconhecer a esterilidade dessa idéia. Assim, quando Day afirma que "a demanda por uma teoria não-linear da justificação inferencial nunca foi trabalhada em detalhe e eu suspeito que isto ocorre porque ela não seja uma hipótese funcional", BonJour responde: "Eu quero mencionar que acho as reflexões de Day sobre a idéia de justificação não-linear úteis e basicamente corretas" (ambas as citações são da coletânea organizada por Bender (1989). A primeira é do comentário de Timothy Day (p. 139) e a segunda é a sentença final do ensaio que BonJour escreve a titulo de réplica ao conjunto de críticas reunidas naquela coletânea (p.292)). 
A solução que aponto para este suposto dilema - solução já indicada na seção anterior - é tomar o termo 'justificação', num sentido que passe ao largo da sua tradicional forma inferencial e argumentativa. É certo que destacar a inferencialidade da justificabilidade é um movimento radical a ser feito na investigação da estrutura da justificação epistêmica. O problema é compreender como a coerência pode produzir justificação de uma maneira que não seja inferencial. Afinal, que eu possa construir um argumento válido, dotá-lo de premissas verdadeiras e, assim, obter corretamente uma conclusão verdadeira é compreensível. Que desta maneira eu esteja justificado em crer na conclusão desse mesmo argumento é igualmente compreensível. ${ }^{27}$ Mas como a coerência pode produzir a justificação? A carência de uma resposta para essa questão poderia nos deixar no mesmo beco sem saída em que vimos estancar a proposta de uma inferência não-linear.

De modo geral, creio podermos assumir que, embora a elaboração de distinções seja uma parte essencial dos procedimentos de análise filosófica, nenhuma distinção pode ter sucesso se não for possível esboçar uma idéia suficientemente clara dos critérios a partir dos quais a distinção deveria ser entendida. O fracasso da proposta de distinção inferência linear/inferência não-linear pode ser atribuído à circunstância de que não é possível compreender o que distinguiria, afinal de contas, um de tais supostos tipos de inferência do outro. E esta circunstância nos leva à conclusão de que, simplesmente, não vale a pena manter a distinção. Se, ao ver as coisas deste modo, as vejo corretamente, então a distinção entre justificação linear e justificação sistêmica depende de que eu possa produzir uma resposta razoável à questão que pergunta pela natureza deste último tipo de justificação.

Acredito que uma resposta razoável a essa questão possa de fato ser produzida. Pretendo fazer isso com dois movimentos complementares. Ocuparei as duas próximas seções deste trabalho para desenvolver esses movimentos. Primeiro, abordarei a justificação epistêmica desde um ângulo que, espero, colocará em evidência certos aspectos da justificação de crenças desde os quais a distinção que proponho parecerá menos excêntrica. A esse movimento dedicarei a próxima seção. Depois, na sétima seção, proporei uma análise da estrutura e do processo da justificação que julgo tornar a noção de justificação sistêmica não apenas razoável, mas, inclusive, indispensável.

27 Cuidado, porém: nada disso implica em que a caracterização do que seja uma inferência seja algo simples. A esse propósito, vale a pena lembrar as palavras de Robert Tragesser no verbete "Inference" do Companion to epistemology: "Chegar a uma boa e adequada caracterização da inferência - e mesmo resolver o que iria contar como uma boa e adequada caracterização aqui - é um problema filosófico difícil e de nenhuma maneira praticamente resolvido" (Dancy \& Sosa, 1992, p. 206-7). 


\section{Posse, uso e exibição da justificação}

Considere o processo de justificação epistêmica do seguinte modo: a avaliação de uma crença não pode partir senão das crenças de que já disponho. O meu sistema doxástico pode ser tomado como sendo o tribunal desde o qual em última instância julgarei da propriedade ou impropriedade de minhas próprias crenças. Onde mais, de todo modo, poderia eu instituir um semelhante tribunal? Mas tal tribunal não está em sessão ininterrupta. Como todo tribunal, também aquele formado pelo conjunto de minhas crenças entra em atividade apenas quando o desacordo e a dúvida são gerados.

Com efeito, não é razoável esperar que o conjunto inteiro de minhas crenças seja aqui e agora convocado para decidir da justificabilidade da crença, digamos, de que estou agora (no momento mesmo em que escrevo estas linhas) diante de uma tela de computador. Não se trata de afirmar que tais crenças tenham algum tipo de imunidade justificatória, alguma infalibilidade que as isente de quaisquer requisitos de justificação. Qualquer um dos familiares cenários céticos - um sonho, uma alucinação, uma deficiência neurológica, para ficarmos com os mais comuns - poderia sugerir a necessidade da apresentação de algum tipo de credencial epistêmica à crença de que estou agora diante de uma tela de computador. Esta sugestão, no entanto, não é própria senão de contextos bastante inusuais.

Aqui cabe o velho paralelo jurídico. Somos todos o mais das vezes merecedores de uma presunção de inocência diante de qualquer imputação legal. Em situações excepcionais essa presunção pode ser revogada, mas não é razoável esperar que tenhamos de responder a todas e quaisquer acusações que nos sejam feitas em todas e quaisquer circunstâncias que elas o sejam. Assim, também, muitas de nossas crenças ordinárias têm a seu favor uma espécie de presunção de justificação, e não é razoável esperar que demos conta de toda e qualquer justificação disponível para nossas crenças em toda e qualquer circunstância em que essas crenças ocorram.

Não estou dizendo simplesmente que em muitas situações estamos isentos de mostrar a justificação de que dispomos para uma certa crença. Argumentar por isto seria argumentar por aquilo que, suponho, poucos disputariam. É muito claro que há inúmeros casos em que não deveria ser exigido que exibíssemos nossa justificação. Para ver por que isto é assim, basta considerar os casos mais simples de situações cotidianas nas quais nos assumiríamos justificados. Fôssemos, em cada uma dessas situações, negar a presença da justificação a menos que todo o sofisticado aparato cognitivo necessário para exibirmos a justificação de que dispomos estivesse em movimento, a vida de nossa mente seria muito mais atribulada do que ela já o é em circunstâncias normais.

Pior ainda, essa exigência muito provavelmente conduziria à revogação da justificação de que, em muitos casos, dispomos. Com efeito, deveria ser declarada ilegítima, a ser dado curso a uma tal exigência, toda justificação de que não fôssemos capazes de oferecer uma elaboração manifesta. Ocorre, porém, que parece 
inevitável aceitar que não somos capazes de cumprir essa exigência em todos os casos. Particularmente, podemos imaginar, no caso de pessoas pouco dotadas intelectualmente e daquelas que jamais tenham adquirido, através de uma educação formal ou por qualquer outro meio, as ferramentas lógicas e conceituais necessárias para levar a cabo uma reflexão sobre sua própria performance cognitiva. Condição indispensável para a exibição da justificação de que se dispõe, tais ferramentas não o são, entretanto, para a obtenção da justificação nas situações mais simples e banais. Distinguir um e outro gênero de caso, portanto, nos permite preservar a atribuição da justificação a muitas circunstâncias em que não seria razoável esperar que a negássemos.

Se esta reflexão está correta, então nós podemos estar justificados em crer numa certa proposição $p$ sem que isso implique ou exija que exibamos a justificação de que dispomos para $p$, nem sequer que tenhamos a possibilidade de exibi-la. Num tal caso, ainda que estejamos justificados em crer que $p$, não mostraremos que o estamos. Porém, em tal caso, o problema com o qual nos enfrentamos dirá respeito à capacidade de articularmos, digamos, lingüística e conceitualmente, nossa justificação. Ora, este problema interessará talvez para destacarmos as limitações lingüísticas e conceituais que nos caracterizam. De maneira mais geral, a necessidade de explicitarmos a justificação de que dispomos poderá destacar nossas limitações cognitivas. Dependendo das nossas circunstâncias e do grau destas limitações, essa necessidade destacará um problema que precisamos resolver. Mas este problema não terá particular relevância se o que buscamos é - como aqui estamos fazendo - simplesmente entender quais são os elementos envolvidos numa situação de justificação epistêmica completa e bem-sucedida.

Não se trata, portanto, de que eu possa crer justificadamente numa certa proposição sem que, ao mesmo tempo, eu mostre que esteja justificado nessa crença. ${ }^{28}$ Penso aqui, em vez disso, em algo como a diferença que é às vezes colocada em termos da propriedade da justificação possuída por uma crença e da atividade de justificarmos essa mesma crença. Neste caso, apontamos para a diferença que existe entre algo que temos e algo que fazemos, entre a posse e o uso da justificação. ${ }^{29}$ Esta distinção se aproxima bastante da maneira como eu mesmo gostaria de caracterizar os aspectos fundamentais envolvidos num processo de justificação epistêmica.

28 Devo destacar, no entanto, que o sentido mais restrito e rigoroso da expressão 'exibir justificação' não deve ser entendido como um sentido insustentável ou sumariamente condenado como uma mera confusão entre os níveis epistêmico e meta-epistêmico, acusação com alguma freqüência dirigida contra os defensores dessa interpretação. Na medida em que assumirmos que um agente doxástico deve poder dar conta das razões ou evidências desde as quais sustenta uma sua crença, não será descabido exigir-lhe algum tipo de avaliação epistêmica de tais razões ou evidências. BonJour é um dos autores que defende essa interpretação mais exigente da justificação epistêmica e que, em função dessa defesa, sofre tal acusação (veja BonJour, 1989, p.277).

29 Matthias Steup (1996, p. 10) e William Alston (1985, p. 23), entre muitos outros epistemólogos, colocam a distinção nestes termos. 
Uma distinção, talvez equivalente a esta, que outros autores fazem a propósito da justificação epistêmica coloca, de um lado, a justificação proposicional e, de outro, a justificação doxástica. A forma proposicional da justificação é comumente entendida como sendo a abordagem que destaca o conjunto das evidências presentes no sistema doxástico de uma pessoa, evidências estas que poderiam justificar uma determinada crença. O ponto chave aqui é que, desde este ponto de vista, a pessoa pode ser dita dispor de justificação independentemente de ela de fato sustentar tal crença exatamente com base naquelas evidências. Por contraposição, a forma doxástica da justificação é comumente entendida como sendo a abordagem que destaca a justificação de que uma pessoa dispõe quando ela efetivamente sustenta uma crença com base na evidência apropriada. ${ }^{30}$ Se tiver justificação proposicional para crer que $p$, então há um sistema de proposições à minha disposição que torna $p$ (provavelmente) verdadeira. Este sistema pode se considerado - e é assim que o tratarei aqui - como o conjunto das evidências de que disponho. Observe que, no caso da justificação proposicional, não se trata de que eu esteja envolvido num processo de decisão a respeito de qual atitude doxástica assumir diante de $p$ - não se trata, portanto, de decidir se devo crer, descrer, ou suspender o juízo acerca de $p$. O que está em jogo aqui é unicamente se, à luz do sistema de proposições de que $p$ faz parte, esta proposição é ou não (provavelmente) verdadeira.

Quer coloquemos a distinção em termos da diferença entre a posse e o uso da justificação, quer a coloquemos em termos da diferença entre as formas proposicional ou doxástica da justificação, uma mesma questão está em jogo aqui. Considerarmos a justificação enquanto algo que pode se apresentar numa variedade proposicional e numa variedade doxástica, no entanto, traz consigo ao menos uma vantagem metodológica sobre a distinção entre posse e uso da justificação. Essa vantagem é que ela imediatamente nos conduz a uma reflexão que já posterguei demasiadamente. Ocorre que, desde o princípio deste trabalho, tenho falado de crenças em proposições. Mas o que são crenças e o que são proposições? ${ }^{31}$

A forma, ao mesmo tempo mais clara e mais direta, de dar resposta a estas questões talvez seja partindo de uma definição elementar de crença. Eis aqui uma: crenças “(...) são um estado psicológico disposicional em virtude do qual uma pessoa irá assentir a uma proposição sob certas condições" ${ }^{32}$ Ora, se a crença é uma disposição para dar assentimento a uma proposição, então é a proposição à qual tal assentimento será dado que guarda a chave para a resposta à questão que

30 Roderick Firth, em “Are epistemic concepts reducible to ethical concepts?" (1978), foi quem primeiro apresentou uma distinção em tais termos.

31 É claro que não tentarei responder realmente estas questões aqui. A discussão que elas colocam ultrapassa em muito os limites deste trabalho. Utilizo-as apenas para lançar alguma luz sobre a curiosa relação que liga crenças e proposições.

32 A definição que tomo por exemplar é a de Paul K. Moser, do verbete "Belief" do The Cambridge dictionary of Philosophy. 
nos ocupa. É assim que a pergunta pela natureza da crença conduz imediatamente à pergunta pela natureza da proposição. ${ }^{33}$ Ora, ocorre que uma das maneiras mais comuns de entender o que seja uma proposição é tomá-la como sendo o objeto de certas atitudes mentais - entre as quais se inclui, claro, a própria crença. De modo que encontramos aqui uma curiosa circularidade. Esta circularidade não é necessariamente viciosa, nem eu a tomarei aqui como o sendo. Tomá-la-ei simplesmente como um indicador de uma singular relação que vigora entre crenças e proposições.

Pois, se a proposição pode ser entendida como sendo o conteúdo assertivo de uma crença, e se a crença pode ser entendida como sendo o assentimento a uma proposição, então podemos aprender alguma coisa sobre a noção de proposição tomando como primitiva a noção de crença e vice-versa. Se este procedimento for correto, poderemos, ao fim e ao cabo, obter um esclarecimento mais amplo da própria noção de justificação epistêmica.

E é exatamente isso o que tentarei fazer em seguida. ${ }^{34}$

\section{Justificação proposicional e justificação doxástica}

Poderia parecer que a mera consideração das evidências disponíveis, evidências que fornecem a matéria-prima da justificação, deixa de lado o aspecto mais relevante da justificação epistêmica. Não obstante, esta consideração é, creio, não apenas provida de méritos analíticos, mas também fundamental para a compreensão da relação entre a estrutura e o processo da justificação epistêmica. Senão, atente para o que segue.

A proposição $p$ "Hoje é sexta-feira" pode estar proposicionalmente justificada para mim, ainda que eu não a tivesse considerado até um instante atrás. Com efeito, outras tantas proposições que compõem a evidência total de que disponho - entre as quais se encontra, digamos, a proposição q, "Ontem foi quinta-feira" - podem estar proporcionando à $p$ tal justificação. E ocorre que a proposição $q$, ela própria, é uma proposição que deverá estar justificada à luz de minhas outras evidências entre as quais se encontram, supostamente, $p$. Se este é o caso, eu não estou incorrendo em nenhum raciocínio falacioso, pois não há qualquer raciocínio sendo articulado aqui.

Do ponto de vista da justificação proposicional, o que interessa é apenas determinar que evidências tenho à minha disposição e, deste ponto de vista, não parece haver qualquer problema em supor que $p$ possa ser parte das evidências disponíveis para $q$ ou que $q$ seja parte das evidências disponíveis para $p$. Ambas

${ }^{33}$ E esta talvez seja uma das perguntas mais difíceis, não apenas da Filosofia da Linguagem, mas de toda a Filosofia. Iacona (2002) oferece um breve, sistemático e esclarecedor roteiro do emaranhado de problemas em que nos metemos quando perguntamos pela natureza das proposições.

34 A descrição do processo de justificação que se segue tem como base algumas sugestões de Keith Lehrer, sugestões estas para as quais Cláudio de Almeida me chamou a atenção em discussões acerca dos problemas aqui em questão. Minhas longas conversas com Tito Flores e com a posição infinitista que ele defende foram igualmente fundamentais para a elaboração desta proposta coerentista. 
as proposições dispõem de justificação proposicional porque há um conjunto de evidências que as tornam altamente prováveis, conjunto este que elas próprias ajudam a compor. Este é o sentido em que essas proposições se sustentam mutuamente. Há circularidade aqui?

Há circularidade no seguinte sentido: se me fosse dado percorrer o sistema inteiro das evidências que em qualquer dado instante me estão disponíveis, ao final desse trajeto eu retornaria ao ponto de partida. Mas não há qualquer interesse em fazer um tal percurso. Fazê-lo apenas me diria, entre outras coisas, que hoje é sextafeira e que ontem foi quinta-feira (e, adicionalmente, que cada uma dessas proposições verdadeiras pode eventualmente ser utilizada para dissipar uma dúvida a respeito da outra, pois a verdade de cada uma delas me dá uma razão para crer na verdade da outra). A circularidade do sistema doxástico não me compromete com qualquer tipo de circularidade viciosa, pois o que está em jogo aqui são simplesmente as articulações que interligam as proposições para as quais teria, num determinado momento, evidência suficiente para as supor verdadeiras. Que tais proposições se relacionem e que as muitas verdades para as quais temos evidência se entreteçam não deveria nos surpreender. Semelhante relacionamento não deve ser confundido com uma forma viciosa de raciocínio. E ele tampouco deveria ser percebido como um tipo misterioso de relacionamento, como mistério que precisa ser metaforicamente protegido pela idéia de uma qualquer rede ou teia. Por que seria misterioso que as proposições se articulem num conjunto coerente de uma maneira tal que possamos perceber caminhos doxásticos de ida e volta entre elas - ainda que, para evitar acidentes catastróficos, não possamos permitir que tais caminhos sejam percorridos simultaneamente num e noutro sentidos?

Sistematizando para sintetizar: é a verdade das proposições de $\alpha$ que torna $p$ (provavelmente) verdadeira e, ao menos em parte, é a (provável) verdade de $p$ que torna $\alpha$ um conjunto de proposições provavelmente verdadeiras. A série coerente é de tal modo estruturada que a justificação disponível para $p$ é dependente da justificação disponível para $\alpha$ e vice-versa. A coerência então distribui e potencializa a justificação ao longo da série de proposições que integram $\alpha$. É importante notar que a justificação disponível para $p$ se articula ao longo de uma série de proposições que não dispõe de um termo último; ao invés, a articulação se estende e a justificação, assim, se distribui tanto quanto queiramos ou necessitemos fazê-lo.

Mas donde afinal - perguntará neste ponto o crítico - saiu a justificação de $p$ ? Qual é a fonte original que gerou a justificação que a estrutura coerente de proposições supostamente distribuiu e potencializou? O problema é que não adianta expulsar a circularidade viciosa da esfera proposicional se ela é preservada na esfera doxástica. Do que realmente se trata aqui é das razões que temos para crer em certas proposições. Pouco importa afirmar, portanto, que a estrutura das proposições não nos compromete necessariamente com a circularidade viciosa, se nossas crenças em tais proposições nos sujeitam exatamente a um tal compromisso. Podemos evitar que esse compromisso, recém-expulso pela porta dos fundos da justificação proposicional, retorne espalhafatosamente pela porta da frente da justificação doxástica? 
Considere novamente a relação entre $p$ e $\alpha$. Suponha que me seja solicitado que explicite de forma argumentativa a razão que tenho para crer que p. Qual é a razão que tenho para crer que $p$ ? Supostamente, $q$. Qual a razão para crer que $q$ ? Supostamente, $r$. E qual a razão para crer que $r$ ? Se agora eu disser ' $p$ ', então estarei assumindo uma forma viciosa de circularidade, uma circularidade doxástica; não o direi, portanto. Ao invés, terei de encontrar uma nova razão, digamos, s. Vamos supor que então meu interlocutor finalmente se sinta satisfeito e conceda que estou justificado em crer que $p$. O ponto a ser destacado aqui é que $p$ estará então sendo justificado porque o articulei em um conjunto doxástico que contém $p, q, r$ e $s$, ou, em outras palavras, estou justificado em crer que $p$ porque estou justificado em crer que $\alpha$. É esta inteira articulação que me dá justificação para crer que $p$.

Claro está, porém, outro interlocutor - ou o mesmo, porém numa circunstância diferente - poderá manifestar insatisfação com a série doxástica que elenquei e exigir que eu explicite a razão que tenho para crer que s. Neste caso, a série deve ser ampliada até que eu encontre uma proposição que meu interlocutor conceda em assumir como objeto de crença justificada. Em tais circunstâncias, $\alpha$ terá de ser reformulado para comportar a(s) nova(s) crença(s). Seja como for, terei ampliado a cadeia doxástica e essa ampliação mesma terá destacado conexões inferenciais entre as proposições em questão e conexões doxásticas entre as crenças nelas. Tais conexões nos proporcionarão uma estrutura a partir da qual novas crenças e novas proposições poderão ser apreciadas. A possibilidade e a freqüente necessidade da reedição de um processo semelhante a propósito de muitos temas e em muitas circunstâncias diferentes compõem um tecido doxástico justificado. Que as crenças individuais que componham um tal tecido sejam derivativamente identificadas como justificadas elas próprias é um fenômeno que podemos compreender se prestarmos atenção aos limites provisórios dentro dos quais se encontram os processos de justificação doxástica nos quais nos ordinariamente vemos envolvidos.

Observe que é o estabelecimento de uma seqüência doxástica articulada isto é, o estabelecimento de $\alpha$ - que proporciona a justificação para $p$. Cada elo integrado a essa seqüência faz com que a seqüência seja ampliada e essa ampliação nos compromete, por sua vez, com - ao menos - a suspensão do juízo a respeito da proposição que o novo elo doxástico propõe. Assim, posso crer que $p$ e essa crença pode estar justificada sem nunca ter sido desafiada; neste caso, a crença de que $p$ estará justificada, pura e simplesmente, a partir do conjunto de proposições que $p$ integra. Se, no entanto, a crença de que $p$ for desafiada, posso oferecer minha crença de que $q$ como razão para $p$. Repare que, nesta hipótese, ou q é reconhecidamente verdadeira ou, ao menos, terei suspendido a crença acerca da verdade de $q$. No primeiro caso, a justificação de $p$ já estará estabelecida; no segundo, necessitarei ampliar a série justificatória apelando à crença de que $r$. 
Observe ainda que, se $p$ desde o princípio esteve em questão, é porque suspendi o juízo acerca desta proposição; se q foi oferecida e não foi sumariamente rejeitada como uma razão para crer que $p$, então $q$ também foi objeto de uma suspensão de juízo e foi considerada, em alguma medida, uma proposição relevante face à $p$; se, finalmente, $r$ foi aceita como justificação para $p$, então é porque esta proposição foi tomada como verdadeira e relevante para aceitar a verdade de p. Neste caso, o conjunto $\alpha$ - aqui pensado como sendo composto pelas crenças em $p$, q e $r$ - é um conjunto que está doxasticamente justificado. Nesta situação, a crença de que $r$ ela própria não dispõe de justificação doxástica: não há em $\alpha$ qualquer proposição $s$ que justifique a crença de que $r$. E, não obstante, direi que a crença de que $r$ está justificada. Por quê? Porque $r$ compõe $\alpha$ e $\alpha$ nos dá justificação para crer que $p$. Se $r$ ela própria vier a ser questionada, então $\alpha$ terá de ser ampliado de modo a conter (ao menos) a crença de que $s$, crença que também estará justificada por sua composição no sistema doxástico em questão.

É importante notar que a possibilidade de justificação da crença de que $r$ a partir da crença de que $s$ - quando e se uma situação o exigir - não é o que justifica, seja (diretamente) $\alpha$, seja (indiretamente) p. É claro que deve haver disponível uma proposição $s$, ela própria justificada, para que a crença de que $r$ esteja justificada. Se não existir uma tal proposição, então a justificação disponível para $p$ eventualmente se revelará uma ilusão. Mas não é existência suposta de tal proposição, não é $s$ que nos dá justificação para crer que $p$ : o que produz a justificação é a pertença de $p$ ao conjunto $\alpha$, conjunto que sobreviveu ao escrutínio doxástico a que o submetemos e que já não é desafiado. Que a crença de que $p$ esteja justificada, terá dependido de que cada elo doxástico tenha cumprido apropriadamente o papel que lhe cabe na cadeia da justificação. A crença de que $r$, muito particularmente, cumprirá o papel justificatório apropriado porque ela compõe adequadamente o conjunto $\alpha$ ao se mostrar relevante para a crença na proposição inicialmente em questão, com o que a crença de que $r$ se articula com a crença de que $q$ e com a crença de que $p$ de modo a liberar-nos da necessidade de prosseguirmos no exercício doxástico da justificação. ${ }^{35}$

Sistematizando para sintetizar: a coerência de um conjunto de crenças é o elemento chave da justificação das crenças que compõem esse conjunto na medida em que estas se revelam, primeiro, suficientemente relevantes para a crença a ser justificada e, segundo, como compondo um conjunto doxástico onde cada elo se mostra inicialmente submetido a uma suspensão de juízo a respeito da verdade da proposição que cada crença tem por objeto. Se for de crença justificada que realmente se trata, eventualmente o recuo doxástico alcançará uma instância na qual a seqüência de crenças se articulará de tal modo que já não se mostrará razoável manter a atitude de suspensão de juízo; ao invés, uma atitude doxástica de crença

5 Talvez seja importante destacar que a estrutura doxástica que a crença nas proposições de $\alpha$ compõe seja uma estrutura de algum modo circular. Isso porque, ainda que a justificação seja unidirecional - já que ela vai de $r$ para $q$ e de $q$ para $p$, mas não o contrário -, é a articulação inteira que sustenta a crença de que $p$. 
se imporá. Esta imposição se destacará mais evidentemente sobre o último elo da cadeia justificatória, mas a justificação deve ser remetida ao conjunto de crenças que foi articulado, pois é o fato de uma tal articulação ter-se revelado possível que proporciona justificação à crença de início desafiada.

Que novas crenças devam poder ser adicionadas à cadeia doxástica se um legítimo questionamento voltar a impor-se é condição necessária da justificação. No entanto, a consideração exclusiva desta exigência deixa de explicar por que (e onde) podemos deter o processo de justificação epistêmica sem que esta justificação seja perdida. É a coerência entre as crenças obtidas nesse processo que assegura a possibilidade de parada (ainda que provisória) do processo de justificação. ${ }^{36}$ Dar conta desta possibilidade é, creio, um dos méritos do coerentismo. E este mérito não é pequeno.

\section{Uma nota socrática, como conclusão}

O coerentismo, tal como ele foi concebido neste trabalho, dirige nossa atenção para o aspecto sistêmico da justificação epistêmica e a consideração deste aspecto sistêmico permite pensar mais claramente sobre a distinção entre a estrutura e o processo da justificação epistêmica. Pois, argumentei, particularmente na quinta seção deste trabalho, que a estrutura e o processo da justificação não deveriam ser pensados de forma estanque - ao modo, digamos, de uma relação entre continente e conteúdo. Isto porque é o processo da justificação que gera a sua estrutura. O que não deve ser tomado como implicando, no entanto, que ambos os aspectos não possam ou devam ser de algum modo distinguidos.

De fato, a distinção entre a justificação de tipo proposicional e a justificação de tipo doxástica, que procurei desenvolver, pretende justamente dar conta desses dois aspectos complementares desde o qual a justificação sistêmica pode ser investigada. A idéia é de que a estrutura da justificação pode ser mais bem compreendida desde a perspectiva proposicional, enquanto que o processo da justificação pode ser mais bem compreendido desde a perspectiva doxástica. Tentei oferecer neste trabalho uma descrição de ambas as perspectivas que parecesse razoável. Se tive sucesso nessa tentativa, não terei feito senão ajudar a situar o coerentismo no rol das propostas que requerem uma consideração mais atenta. E este, claro, não é o ponto onde as questões filosóficas escasseiam, mas sim aquele em que elas ganham impulso.

Seria talvez desnecessário lembrar que tanto a noção de justificação sistêmica, quanto a estratégia de defesa coerentista diante da acusação de circularidade que aqui empreguei assumem supostos disputáveis em uma área de investigação

${ }^{36}$ A incapacidade de dar conta da legitimidade de tais pontos de parada provisórios é, de meu ponto de vista, a razão pela qual a proposta infinitista deveria ser aceita como uma descrição apropriada do processo de justificação epistêmica, mas não da sua estrutura. 
que já é, como um todo, permeada por questões complexas e sutis. As análises a respeito de tais temas aqui desenvolvidas devem, portanto, ser mais adequadamente consideradas como uma sugestão proposta ao exame da comunidade epistemológica do que como uma simples descrição de resultados de algum modo estabelecidos. Elas são sobretudo o fruto de interessada e insistente reflexão e carregam consigo a pretensão de contribuir ativamente para o debate epistemológico contemporâneo. Neste debate, as condições de sobrevivência são ásperas e somente as mais fortes teorias sobrevivem. É na esperança de que a proposta aqui apresentada possa suportar esse teste de sobrevivência que eu a formulo. Na hipótese negativa, no entanto, me restará ao menos o consolo dirigido por Sócrates a Teeteto: "se depois disto (...) voltares a conceber, e conceberes mesmo, ficarás cheio de melhores frutos, graças à presente investigação. Mas se continuares vazio, serás menos incômodo aos de tua companhia, porque mais dócil e compreensivo, visto não imaginares saber o que não sabes". ${ }^{37}$

\section{Referências}

ALMEIDA, Cláudio de. Coherence, defeasibility and the Preface Paradox. Comunicação apresentada no III Simpósio Internacional Principia, Florianópolis, 2003.

ALSTON, William. Concepts of epistemic justification. In: The Monist 68: 57-89, 1985. As páginas referidas são as da coletânea de Moser (1986).

ANNIS, David B. A contextualist theory of epistemic justification. In: American Philosophical Quarterly 15 (1978): 213-219, 1978. As páginas referidas são as da coletânea de Moser (1986).

ARISTÓTELES. Selections. Translated by Terence Irwin and Gail Fine. Cambridge: Hacket Publishing Co., 1995.

AUDI, Robert. Belief, justification and knowledge. Belmont, California: Wadsworth, 1988.

BENDER, John (Editor). The current state of the coherence theory: critical essays on the epistemic theories of Keith Lehrer and Laurence BonJour. Dordrecht: Kluwer Academic Publishers, 1989.

BONJOUR, Laurence. The coherence theory of empirical knowledge. In: Philosophical Studies 30 (1976): 281-312, 1976. As páginas referidas são de Moser (1986).

. The structure of empirical knowledge. Cambridge, Mass.: Harvard University Press, 1985.

COHEN, Stewart. Contextualism, skepticism, and the structure of reasons. In: Philosophical Perspectives, 13, Epistemology, 57-89, 1999.

DANCY, Jonathan; SOSA, Ernest (Editores). A companion to epistemology. Oxford: Blackwell, 1992.

DAVIDSON, Donald. A coherence theory of truth and knowledge. In: A. A. MALACHOWSKI (Editor). Reading Rorty. Oxford: Blackwell, 1990. Reimpresso em BERNECKER, Sven, DRETSKE, Fred (2000): 413-428.

DAY, Timothy Joseph. Circularity, non-linear justification, and holistic coherentism. In: BENDER, John (Editor). The Current state of the coherence theory, p. 134-141, 1989.

37 O comentário de Sócrates é oferecido ao personagem que leva o nome do diálogo como um consolo diante da impossibilidade de se alcançar ali uma definição satisfatória do conhecimento (Teeteto, $210^{\circ}$ ). 
DeROSE, Keith. Solving the skeptical problem. The Philosophical Review, v. 104, n. 1, 1-52, 1995.

FIRTH, Roderick. Are epistemic concepts reducible to ethical concepts? In: GOLDMAN, A. I., KIM, J. (Editores). Values and morals, Dordrecht: D. Reidel, 1978.

FLORES, Tito A. Racionalidade epistêmica e o processo de justificação. Porto Alegre. Tese (Doutorado em Filosofia) - Faculdade de Filosofia e Ciências Humanas, PUCRS, 2004.

FOLLEY, Richard. Working without a net - a study of egocentric epistemology. Oxford: Oxford University Press, 1993

GETTIER, Edmund. Is justified true belief knowledge? Analysis 23 (1963): 121-23.

IACONA, Andrea. Are there propositions? Erkenntnis 58 (2002): 325-351.

KIRKHAM, Richard L. Teorias da verdade. Tradução de Alessandro Zir. São Leopoldo: Editora UNISINOS, 2003.

KLEIN, Peter. Human knowledge and the infinite regress of reasons. In: Philosophical Perspectives, 13, Epistemology, 1999. Oxford: Blackwell: 297-325.

LEHRER, Keith. Theory of knowledge. 2. ed. Boulder, Colorado: Westview Press, 2000.

LEWIS, David. Elusive knowledge. In: Australasian Journal of Philosophy. V. 74, n. 4, 549-567, 1996.

MOORE, George. Escritos filosóficos. Tradução de Pablo Rubém Mariconda. São Paulo: Nova Cultural, 1989.

MOSER, Paul K. (Editor). Empirical knowledge: readings in contemporary epistemology. Cambridge: Cambridge University Press, 1986.

PLATÃO. Teeteto e Crátilo. Tradução de Carlos Alberto Nunes. Belém: Universidade Federal do Pará, 1988.

SEXTUS EMPIRICUS. Outlines of Pyrrhonism. Translated by R. G. Bury. New York: Prometheus Books, 1990.

STEUP, Matthias. An introduction to contemporary epistemology. New Jersey: Prentice-Hall, 1996. 